\title{
Development for the production of low phosphorus steel in operations at Arcelor Mittal Tubarão(*)
}

\author{
W. Luiz-Corrêa ${ }^{*}$, H. Silva-Furtado** and J.R. de Oliveira***
}

\begin{abstract}
The growing demand to produce steel with lower phosphorus $(\mathrm{P})$ content happens in tandem with the increase in the content of this element in the ores used in the production of pig iron, leading to a constant evolution in the process of steel dephosphorization in BOF converters. Arcelor Mittal Tubarão (AMT), located in the municipality of Serra, Brazil, currently produces 5 million t of steel, but has an installed capacity of 7.5 million. This work aims at showing the development carried out in the dephosphorization of silicon-aluminium killed steel produced in the Arcelor Mittal Tubarão converters. The analysis of process variables such as flux addition, oxygen lance position and temperature at the end of blow are based on classical phosphorus partition models. The results compare phosphorus values in liquid steel before and after modifications in the variables and the refractory wear caused by the new procedures applied to AMT steelmaking converters .
\end{abstract}

\section{Desarrollo para la producción de acero con bajo contenido de fósforo en las operaciones de Arcelor Mittal Tubarão}

\begin{abstract}
Resumen
Con la creciente demanda de aceros cada vez más bajos en fósforo (P), junto con el constante aumento en el contenido de este elemento en el mineral utilizado para producir arrabio, es necesario un proceso en constante evolución para la eliminación de fósforo del acero en los convertidores BOF. Este artículo tiene como objetivo mostrar el desarrollo para reducir el nivel de fósforo en el acero desoxidado con aluminio y silicio producido en los convertidores de Arcelor Mittal Tubarão (AMT), empresa ubicada en el municipio de Serra, Brasil. Este complejo produce 5 millones de toneladas pero tiene una capacidad instalada de 7,5 millones. El análisis de las variables del proceso tales como adición de fundentes, temperatura y el patrón de soplado, se basó en los modelos clásicos de la partición de fósforo. Los resultados presentados comparan los valores de fósforo obtenidos en el acero líquido antes y después de los cambios realizados, y analiza el desgaste de refractarios en los convertidores.
\end{abstract}

Palabras clave

Eliminación de fósforo; Aceros; Convertidores BOF.

\section{INTRODUCTION}

In most steel grades, the phosphorus is considered an undesirable element, which must be reduced as much as possible. The most common way to reduce this element in fully integrated steel-making companies is during the oxygen blowing process in the converters. This paper presents the production development of silicon-aluminium killed steel with phosphorus content below current standards in the final product (slab). Therefore, the purpose of this study is to evaluate the steel dephosphorization process performance of Arcelor Mittal Tubarão converters to meet the demand for low phosphorus, lower than $0.015 \%$ for silicon-aluminium killed steel with manganese higher than $1.0 \%$ in the final product.

Several authors referred to in this paper have studied the process of steel dephosphorization, working with the phosphorus partition coefficient $(L p)$ at the end of the blow, where $(L p)=$ the correlation between phosphorus content in the slag divided by the percentage of this element in steel.

\footnotetext{
(•) Trabajo recibido el día 19 de agosto de 2011 y aceptado en su forma final el día 2 de octubre de 2012.

Steelmaking Reliability Manager-Arcelor Mittal Tubarão, Vitória, ES, Brasil; Email: walter.correa@arcelormittal.com.br

** Arcelor Mittal Tubarão, Vitória, ES, Brasil; Email: henrique.furtado@arcelormittal.com.br

${ }^{* \star *}$ Dpto. of Engineering Materials Prof-IFES, Vitória, ES, Brasil; Email:jroberto@ifes.edu.br
} 
Baljiva $^{[1]}$, Suito and Inoue ${ }^{[2]}$ considered $L p=\frac{\left(\% \mathrm{P}_{2} \mathrm{O}_{5}\right)}{[\%]^{2}}$ Healy $^{[3]}$ and Turkdogan ${ }^{[4]}$ considered $L p=\frac{(\% \mathrm{P})}{[\% \mathrm{P}]}$

These studies try to correlate this parameter with process variables such as the addition of fluxes in the converters (e.g. lime, dolomite, fluorspar), the slag chemical composition at the end of the blow (e.g.: $\%$ total $\mathrm{Fe}, \% \mathrm{FeO}, \% \mathrm{P}_{2} \mathrm{O}_{5}, \% \mathrm{MnO}, \% \mathrm{MgO}$, $\% \mathrm{CaO}, \% \mathrm{SiO}_{2}$ ) and blowing patterns.

The dephosphorization reaction could be considered as ${ }^{[1 \text { and } 2]}$ :

$$
2 \underline{\mathrm{P}}+5(\mathrm{FeO})+3(\mathrm{CaO})=5 \mathrm{Fe}_{(\mathrm{I})}+\left(3 \mathrm{CaO} \cdot \mathrm{P}_{2} \mathrm{O}_{5}\right)_{(\mathrm{s})}
$$

Balajiva $^{[1]}$ suggests a correlation between the phosphorus partition coefficient ( $\mathrm{Lp}$ ) with $\mathrm{CaO}$ (lime), the percentage of total $\mathrm{Fe}$ in slag and temperature, i.e.:

$\log L p=11.80 \log (\% \mathrm{CaO})-5 \log \left(\% \mathrm{Fe}_{t}\right)-\mathrm{C}(2)$

where: $L p=\frac{\left(\% \mathrm{P}_{2} \mathrm{O}_{5}\right)}{[\% \mathrm{P}]^{2}}$

where $C$, is a constant for a given melt temperature: $C=21.13 ; 21.51$ and 21.92 for the melt temperatures of $1550^{\circ} \mathrm{C}, 1585^{\circ} \mathrm{C}$ and $1635^{\circ} \mathrm{C}$ respectively.

The elements or compounds in parentheses are present in the slag and the elements in brackets are dissolved in the steel.

Suito and Inoue ${ }^{[2]}$ changed this formulation, inserting other slag oxides contribution such as ( $\% \mathrm{MgO}, \% \mathrm{P}_{2} \mathrm{O}_{5}, \% \mathrm{MnO}, \% \mathrm{CaF}_{2}$ and $\% \mathrm{Al}_{2} \mathrm{O}_{3}$ ), obtaining the following equation:

$$
\begin{gathered}
\log \mathrm{Lp}=0.145(\% \mathrm{CaO})+0.3(\% \mathrm{Mg} 0)+ \\
+0.5\left(\% \mathrm{P}_{2} \mathrm{O}_{5}\right)+0.3(\% \mathrm{MnO})+ \\
+1.2\left(\% \mathrm{CaF}_{2}\right)-0.2\left(\mathrm{Al}_{2} \mathrm{O}_{3}\right)+ \\
\frac{22810}{\mathrm{~T}}-20.51-5 \log \left(\% \mathrm{Fe}_{\mathrm{t}}\right)
\end{gathered}
$$

For Healy ${ }^{[3]}$ and Turkdogan ${ }^{[4]}$ the dephosphorization reaction could be considered as:

$$
\begin{gathered}
\underline{P}+5 / 2(\mathrm{FeO})+3 / 2(\mathrm{CaO})=2.5 \mathrm{Fe}_{\mathrm{t}}+ \\
\left(1.5 \mathrm{CaO} \cdot \mathrm{PO}_{2.5}\right)_{(\mathrm{s})}
\end{gathered}
$$

Healy ${ }^{[3]}$ proposes a new formulation for (Lp):

$$
\begin{aligned}
& \log L p= 0.08 \cdot(\% \mathrm{CaO})+2.5 \cdot \log \left(\% \mathrm{Fe}_{\text {total }}\right)+(5) \\
& \frac{22350}{T}-16 \pm 0.4
\end{aligned}
$$

where: $L p=\frac{(\% P)}{(\% P)}$

Considering equations ( 3 ) and (5), it could be noticed that an increase in basicity, the iron content in the slag and the reduction of temperature enhance the dephosphorization process, as observed by the increase of the phosphorus partition coefficient.

Turkdogan ${ }^{[4]}$ proposed a correlation of the phosphorus partition coefficient, considering the reaction (6) with a new variable which aims at measuring the slag basic oxides $(\mathrm{BO})$, as follows:

$$
[P]+5 / 2[O]+3 / 2\left(\mathrm{O}^{-2}\right)=\left(\cdot \mathrm{PO}_{4}^{-3}\right)
$$

where: $L p=\frac{(\% P)}{[\% P]}$

$\log (\mathrm{Lp})=0.071 \mathrm{BO}+2.5 \log [\% \mathrm{P}]+\frac{21740}{\mathrm{~T}}-9.87(7)$

where $\mathrm{BO}$ is defined in equation (8):

$$
\mathrm{BO}=(\% \mathrm{CaO})+\left(\% \mathrm{CaF}_{2}\right)+0.3 \cdot(\% \mathrm{MgO})
$$

Equation (7) intends to provide the capacity to absorb phosphorus from the slag in terms of basic oxides, where $\mathrm{CaF}_{2}$ has the same weight as $\mathrm{CaO}$ and $\mathrm{MgO}$ is $1 / 3$ of the $\mathrm{CaO}$ weight. Therefore, fluorspar, as well as the reduction of slag viscosity increasing the reaction kinetics have the same effect in improving the thermodynamic conditions as the $\mathrm{CaO}^{[4]}$.

Notice that an increase in basic oxides and a fall in temperature both decrease the activity coefficient of $\mathrm{P}_{2} \mathrm{O}_{5}$ favoring dephosphorization. Turkdogan and Pearson ${ }^{[5]}$ proposed that the Raoultian activity coefficient " $\gamma_{\mathrm{FeO}}$ " decreases with increasing binary slag basicity $\left(\mathrm{B}=\% \mathrm{CaO} / \% \mathrm{SiO}_{2}\right)$, as shown in table I.

According to the author, a decrease in the " $\gamma_{\mathrm{FeO}}$ " makes the Raoultian activity of $\mathrm{FeO}$ " $\mathrm{a}_{\mathrm{FeO}}$ " also decrease, which causes the reaction (4) to occur towards the decomposition of $\mathrm{CaO} \mathrm{P}_{2} \mathrm{O}_{5}$, which would result in a reduction of the slag capacity to retain phosphorus. 
DEVELOPMENT FOR THE PRODUCTION OF LOW PHOSPHORUS STEEL IN THE OPERATIONS AT ARCELOR MITTAL TUBARÃO DESARROLLO PARA LA PRODUCCIÓN DE ACERO CON BAJO CONTENIDO DE FÓSFORO EN LAS OPERACIONES DE ARCELOR MITTAL TUBARÃO

Table I. Effect of slag basicity on FeO activity coefficient

Tabla I. Efecto de la basicidad de la escoria en el coeficiente de actividad de $\mathrm{FeO}$

\begin{tabular}{lccccc}
\hline $\mathbf{B}=\% \mathrm{CaO} / \% \mathrm{SiO}_{2}$ & 2.0 & 2.5 & 3.0 & 3.5 & 4.0 \\
\hline$\gamma_{\mathrm{FeO}}$ & 2.00 & 1.33 & 1.11 & 0.98 & 0.87
\end{tabular}

Turkdogan ${ }^{[4]}$ affirms, however, that the slag basicity is not the most appropriate parameter to describe the dependence of the phosphorus absorption capacity of the slag. "BO" would be more important.

However, according to Balajiva ${ }^{[1]}$, there is an optimum relation between the $\% \mathrm{FeO}$ in slag, basicity and the phosphorus partition coefficient $(\mathrm{Lp})$ between slag and metal, as shown in figure 1 .

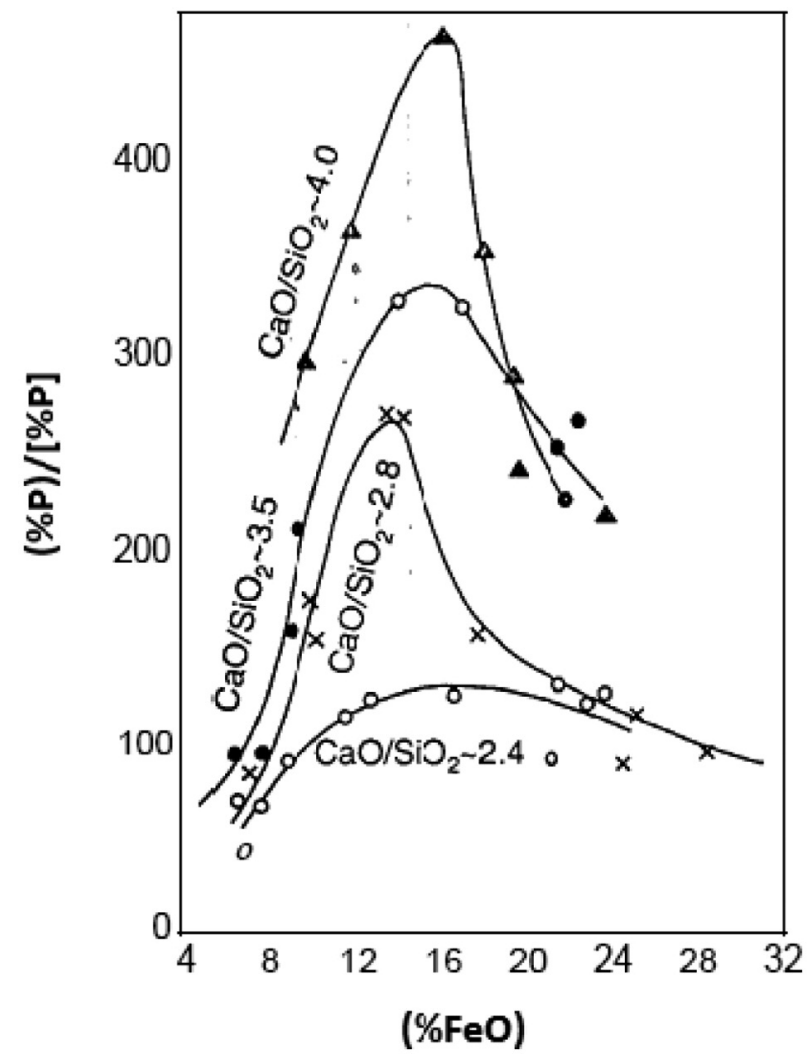

Figure 1. Relation between the $\% \mathrm{FeO}$ in slag, basicity and phosphorus partition $L_{P}=\frac{(\% P)}{[\% P]}$.

Figura 1. Relación entre el \% FeO en la escoria, basicidad y coeficiente de partición del fósforo $L p=\frac{(\% \mathrm{P})}{[\% \mathrm{P}]}$.
Turkdogan and Pearson ${ }^{[5]}$ considered the formation reaction of $\mathrm{P}_{2} \mathrm{O}_{5}$ in slag as:

$$
2 \underline{\mathrm{P}}+5 \underline{\mathrm{O}}=\left(\mathrm{P}_{2} \mathrm{O}_{5}\right)_{(\mathrm{I})}
$$

They also established the expression of the $\mathrm{P}_{2} \mathrm{O}_{5}$ activity coefficient:

$$
\begin{gathered}
\log \gamma_{\left(\mathrm{P}_{2} \mathrm{O}_{5}\right)}=-1.12\left(22 . \mathrm{X}_{(\mathrm{CaO})}+15 . \mathrm{X}_{(\mathrm{MgO})}+\right. \\
+13 . \mathrm{X}_{(\mathrm{MnO})}+12 . \mathrm{X}_{(\mathrm{FeO})}-2 \mathrm{X}_{\left(\mathrm{SiO}_{2}\right)}-42000 / \mathrm{T}+(10) \\
+23.58
\end{gathered}
$$

Notice that as a result of the increase in basicity of $\mathrm{FeO}$ content in slag and a fall in temperature, the $\mathrm{P}_{2} \mathrm{O}_{5}$ activity coefficient decreases, favouring dephosphorization.

\section{EXPERIMENTAL}

In order to develop low phosphorus steel, 12 heats were produced. Changes in the process were based on some of the parameters mentioned before, with focus on variables which enhance the removal of phosphorus during the production process. The methodology was based on current results of phosphorus content in normal grades of steel, changing the process variables in order to increase the phosphorus partition coefficient.

For the production of steel in development, the phosphorus content must be around 50 to $60 \mathrm{ppm}$ lower than the phosphorus specification of the final product, which is of $150 \mathrm{ppm}$, due to the contamination that may occur from the slag carried over from the converter heat tapping to the ladle, and also from the pick-up of phosphorus content in the $\mathrm{Mn}$-Fe-alloy, which is usually added to these steel grades.

The main actions in the process variables in order to achieve the phosphorus partition are described below.

As mentioned before, from all the expressions applied to describe the phosphorus partition 
coefficient, oxidized iron is the variable that affects positively the removal of phosphorus. Thus, it was aimed to achieve lower carbon content in the end of the blow. In fact, oxygen mass balance calculations were made in order to obtain an excess of blown oxygen volume, which allows higher oxidation of carbon, silicon and manganese, also a larger amount of iron oxide in the slag, as it can be seen in table II.

The effect of increasing the amount of flux used during the oxygen blowing was also analysed based on the Turkdogan ${ }^{[4]}$ model (Ec. (7) and (8)). In this case, the $\mathrm{CaO}$ quantities were increased by adding lime, and also fluorspar $\left(\mathrm{CaF}_{2}\right)$ to speed highly basic slag formation. Regarding Si-Al killed steel grades with high manganese, the increase in lime was, on average, of $3 \mathrm{~kg} / \mathrm{t}$ of steel produced and the fluorspar was of approximately $1 \mathrm{~kg} / \mathrm{t}$ of liquid steel. The average net result (Table II) was an increase in basicity (\% $\mathrm{CaO} / \% \mathrm{SiO}_{2}$ ).

Temperature is a highlighted item in all the models showed before and it is inversely proportional to the phosphorus partition coefficient, i.e., lower temperatures enhance the phosphorus removal from the steel. Despite this, high additions of manganese alloys in the bath after steel tapping push the temperature to higher values compared with current grades of steel, to compensate the heat loss. Thus, it was not possible to reduce the temperature values at the end of the blow.

Table II. Average compositions values of hot metal and final slag

Tabla II. Valores medios de la composición del arrabio y escoria final

\begin{tabular}{lrc}
\hline Data & Current & Experimental \\
\hline \multicolumn{2}{l}{ Hot metal composition } & \\
$\% \mathrm{C}$ & 4.55 & 4.49 \\
$\% \mathrm{Si}$ & 0.19 & 0.18 \\
$\% \mathrm{Mn}$ & 0.45 & 0.45 \\
$\% \mathrm{P}$ & 0.08 & 0.08 \\
End point slag data & & \\
Binary basicity & 3.88 & 4.27 \\
$\% \mathrm{MgO}$ & 8.77 & 7.98 \\
$\% \mathrm{FeO}$ & 28.24 & 33.77 \\
$\% \mathrm{CaO}$ & 42.68 & 41.53 \\
$\% \mathrm{Al}_{2} \mathrm{O}_{3}$ & 1.86 & 1.27 \\
$\% \mathrm{MnO}$ & 4.80 & 3.61 \\
$\% \mathrm{P}_{2} \mathrm{O}_{5}$ & 1.87 & 1.48 \\
$\% \mathrm{CaF}\left(^{*}\right)$ & $\sim 0.20$ & $\sim 1.00$ \\
\hline
\end{tabular}

Table III shows the summary of the actions taken in process variables and the impact on the partition coefficient based on the mentioned authors ${ }^{[1-5]}$. All the changes shown in table III were performed simultaneously on all 22 heats. Throughout the production process, all fluxes and materials are added by weighing on certified scales and the data are recorded in the computers in the process. All the process information presented in this report was collected from this database.

Temperature measurements and steel samples were collected by using probes connected to a sub lance which is inserted in the liquid steel bath during and at the end of the blowing. The phosphorus content in steel was analysed at the AMT chemical laboratory by optical spectroscopy and slag samples were analysed using an X-ray diffractometer.

\section{RESULTS AND DISCUSSION}

The results of the phosphorus evolution from hot metal to the final product (slab) in the different experimental heats, after the changes, shown in table III, are shown in figure 2. As it can be seen, there was a strong removal of phosphorus in the stage of oxygen blowing and after a phosphorus reversion in the following process. That occurred because of the slag carried over during the tapping process and from the pick-up of residual phosphorus of Fe-alloys added. The maximum phosphorus reversion for high $\mathrm{Si}-\mathrm{Mn}-\mathrm{Al}$ killed steel was observed to be of $60 \mathrm{ppm}$.

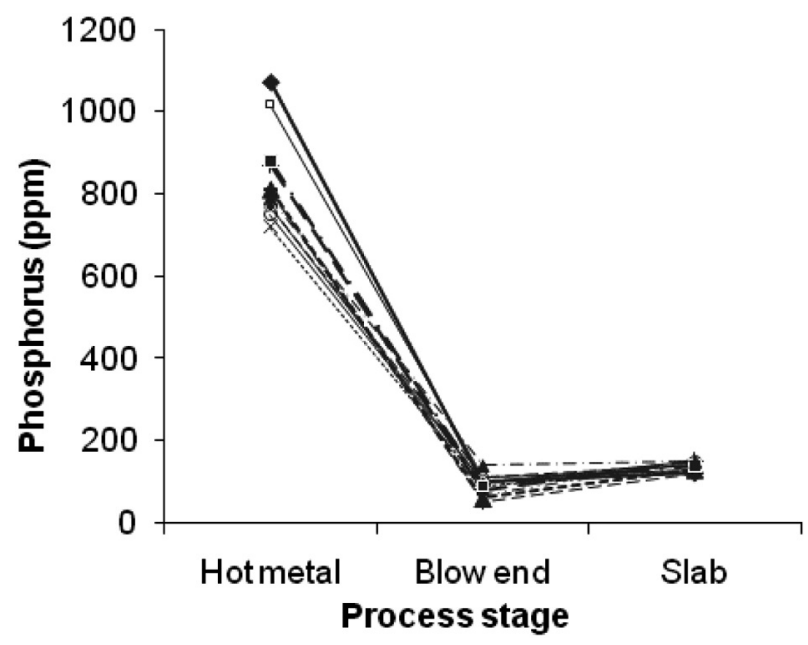

Figure 2. Phosphorus content evolution from hot metal to slabs in the experimental heats.

Figura 2. Evolución del contenido de fósforo desde el arrabio al término del soplado y contenido final en la colada continua. 
DEVELOPMENT FOR THE PRODUCTION OF LOW PHOSPHORUS STEEL IN THE OPERATIONS AT ARCELOR MITTAL TUBARÃO DESARROLLO PARA LA PRODUCCIÓN DE ACERO CON BAJO CONTENIDO DE FÓSFORO EN LAS OPERACIONES DE ARCELOR MITTAL TUBARÃO

Table III. Summary of actions in the process and its impact on the phosphorus partition coefficient

Tabla III. Resumen de las acciones en el proceso y su impacto en el coeficiente de partición de fósforo

\begin{tabular}{|c|c|c|c|c|}
\hline Variables & Action & How & $\begin{array}{c}\text { Result } \\
\text { measurement }\end{array}$ & $\begin{array}{c}\text { Impact on P } \\
\text { (partition } \\
\text { coefficient) }\end{array}$ \\
\hline \multirow{2}{*}{$\begin{array}{l}\text { Steel } \\
\text { oxidation }\end{array}$} & $\begin{array}{l}\text { To increase } \\
\text { oxygen volume }\end{array}$ & $\begin{array}{l}\text { Add more } 3 \mathrm{Nm}^{3} / \mathrm{t} \\
\text { of steel }\end{array}$ & \multirow{2}{*}{$\begin{array}{l}\% \mathrm{FeO} \text { and } \\
\% \mathrm{Fe}_{\mathrm{T}} \text { slag result }\end{array}$} & \multirow{2}{*}{$\uparrow$} \\
\hline & $\begin{array}{l}\text { To modify the } \\
\text { height of oxygen } \\
\text { lance standard }\end{array}$ & $\begin{array}{l}\text { To raise the lance } \\
\text { between } 200 \\
\text { to } 400 \mathrm{~mm}\end{array}$ & & \\
\hline \multirow{2}{*}{$\begin{array}{l}\text { Fluxes } \\
\text { consumption }\end{array}$} & $\begin{array}{l}\text { To increase lime } \\
\text { addition }\end{array}$ & $\begin{array}{l}\text { Add more } 3 \mathrm{~kg} / \mathrm{t} \\
\text { of steel }\end{array}$ & \multirow{2}{*}{ Flux weight } & $\uparrow$ \\
\hline & $\begin{array}{l}\text { To increase } \\
\text { fluorspar addition }\end{array}$ & $\begin{array}{l}\text { Add more } 1 \mathrm{~kg} / \mathrm{t} \\
\text { steel }\end{array}$ & & $\downarrow$ \\
\hline Temperature & $\begin{array}{l}\text { To increase } \\
\text { temperature in the } \\
\text { end of the blow }\end{array}$ & $\begin{array}{l}\text { According to Fe-Mn } \\
\text { addition }\end{array}$ & $\begin{array}{l}\text { Temperature } \\
\text { measurement }\end{array}$ & $\downarrow$ \\
\hline
\end{tabular}

The results of the average values in the end of the blow and in the slab of current and experimental heats, are shown in table IV.

The phosphorus removal efficiency in the experimental heats is compared to the current ones through figure 3 . Actually, it is observed that in general, phosphorus partition coefficients (Lp) were higher than the current ones, endorsing the plan of action reported in table 2 . This result is due to an increase of $\% \mathrm{FeO}$ in the slag, the higher addition of $\mathrm{CaF}_{2}$, as well as to an increase in the oxygen available to form $\mathrm{P}_{2} \mathrm{O}_{5}$, as shown in table II. All these actions

Table IV. Average values in the end of the blow and in the slab of current and experimental heats

Tabla IV. Valores medios al término del soplado y el contenido final en la colada continua en las coladas de operación de prueba $y$ las regulares

\begin{tabular}{|c|c|c|}
\hline Data & Current & Experimental \\
\hline $\begin{array}{l}\text { End point steel } \\
\text { \% C } \\
\qquad \text { O (ppm) } \\
\text { T }\left({ }^{\circ} \mathrm{C}\right) \\
\% \mathrm{P} \\
\text { Lp }\end{array}$ & $\begin{array}{c}0.049 \\
873 \\
>1680^{\circ} \mathrm{C} \\
0.0140(\sigma=0.004)^{*} \\
55\end{array}$ & $\begin{array}{c}0.042 \\
903 \\
>1680^{\circ} \mathrm{C} \\
0.0093(\sigma=0.002) \\
68\end{array}$ \\
\hline $\begin{array}{l}\text { Final P content in } \\
\text { the slab (average) }\end{array}$ & $0.017(\sigma=0.003)^{*}$ & $0.013(\sigma=0.002)^{*}$ \\
\hline
\end{tabular}




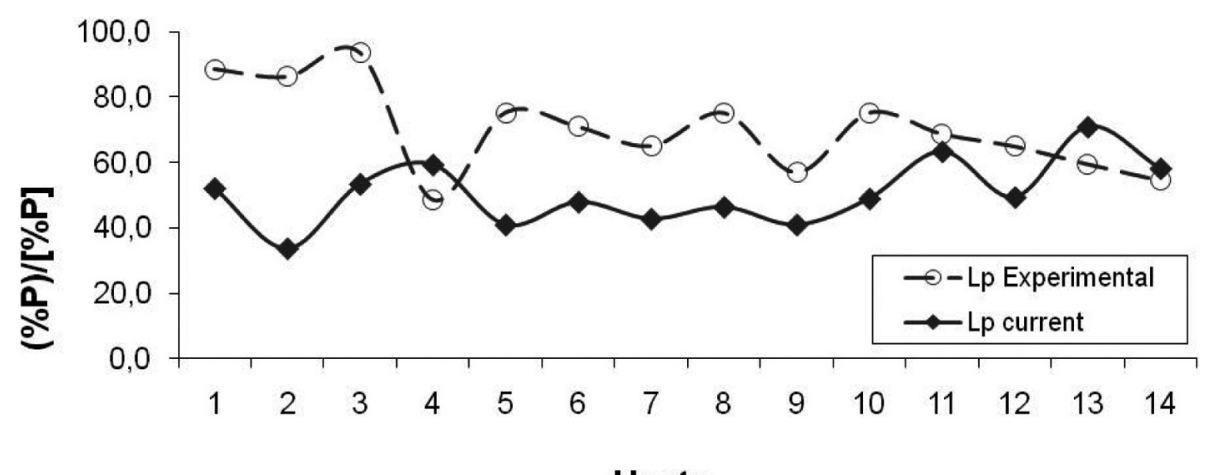

Heats

Figure 3. Phosphorus partition coefficient in the converter, in the current and experimental heats, where $L p=\frac{(\% P)}{[\% P]}$.

Figura 3. Coeficiente de partición del fósforo en las coladas de operación de prueba y las regulares, donde $L p=\frac{(\% P)}{[\% P]}$.

associated decreased slag viscosity and enhanced dephosphorization kinetics. On the other hand, an increase in the addition of $\mathrm{CaO}$, supports the dephosphorization thermodynamically, by reducing the $\mathrm{P}_{2} \mathrm{O}_{5}$ activity, also offering a higher amount of $\mathrm{CaO}$ to fix the $\mathrm{P}_{2} \mathrm{O}_{5}$ in slag, according to reaction: $\mathrm{P}_{2} \mathrm{O}_{5}+3 \mathrm{CaO}=\mathrm{P}_{2} \mathrm{O}_{5} .3 \mathrm{CaO}$.

The results reassure the relation of empirical models to describe the phosphorus partition coefficient, despite the wide dispersion when compared to industrial data.
Figure 4 shows the distribution of phosphorus content at the end of blow of current and experimental heats. As can be seen in the figure, phosphorus occurrence frequency is lower than $0.015 \%$ was always higher than the experimental heats, and the occurrence of phosphorus above $0.015 \%$, was always higher than the current ones. These results show that the process changes, according to table III, were effective to ensure results below or equal to $0.015 \%$ of phosphorus content in the final product (slab). This occurred due to the same reasons aforementioned.

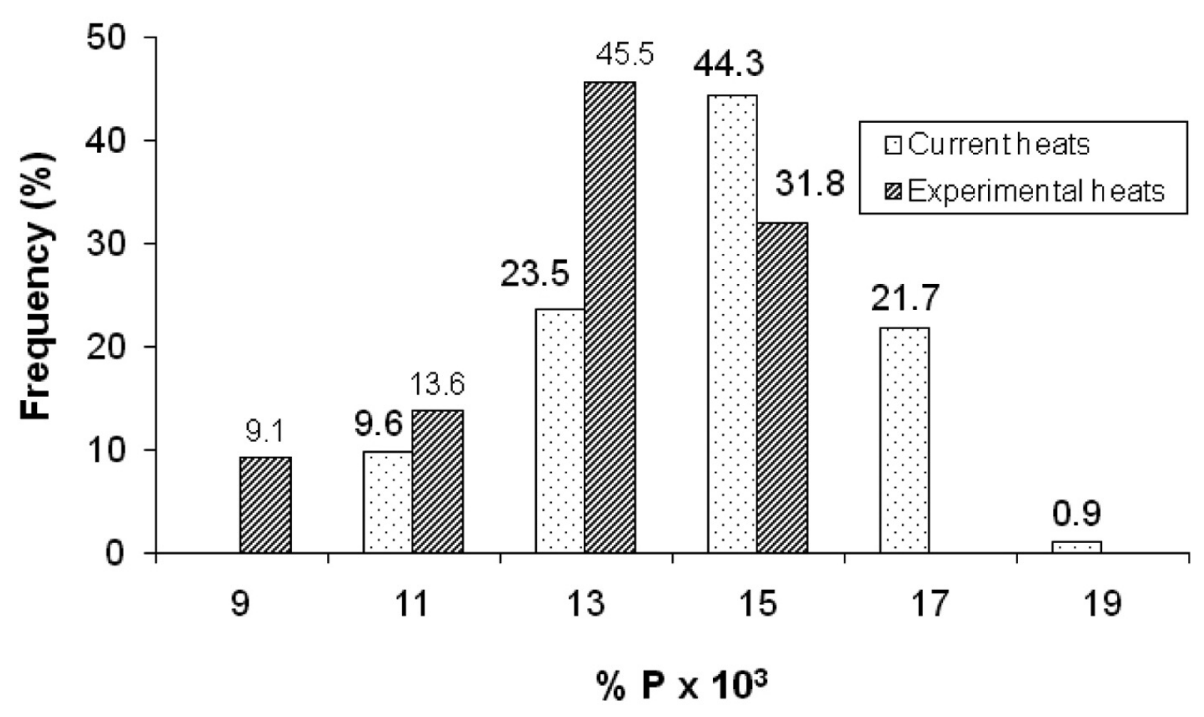

Figure 4. Frequency of phosphorus content in the final product (slab) comparing current heats with experimental heats.

Figura 4. Distribución de la composición de fósforo en las coladas de operación de prueba y las regulares. 
Despite the good results of the tests regarding the phosphorus content at the end of the blow for experimental heats, the converter refractory wear index, evaluated from bricks thickness measurements, was significantly higher than in the current heats, as it can be seen in figure 5 . This undesirable effect is due to the higher $\mathrm{FeO}$ content in slag, and also the increase in fluorspar addition. Both procedures aim to decrease slag viscosity, which increases refractory wear. High temperatures at the end of the blow also contribute to increase refractory wear.

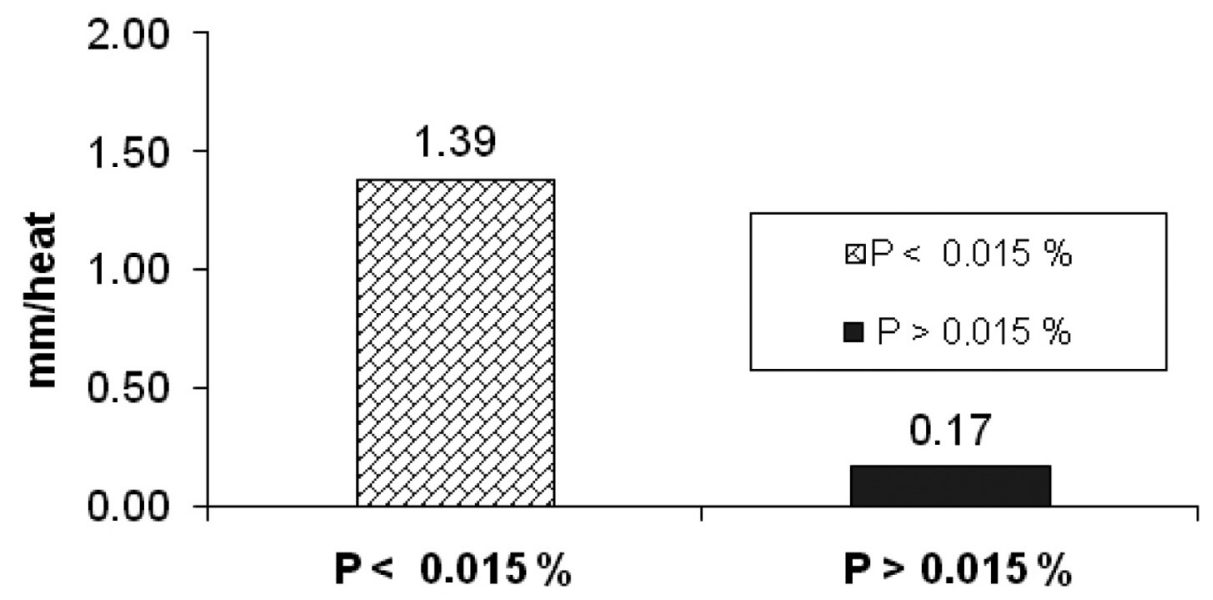

Figure 5. Refractory wear rate in converters for current heats $(P \geq 0.015)$ and experimental heats $(P \leq 0.015)$.

Figura 5. Desgaste refractario de los convertidores en las coladas de operación de prueba $(P \leq 0,015)$ y las regulares $(P \geq 0,015)$.

\section{CONCLUSIONS}

- The dephosphorization results of experimental heats were significantly higher than the current ones.

- Higher phosphorus removal in the experimental heats is mainly due to:

An increase of oxidation level of the system; Changes made in the process, such as the increase of oxygen volume and blow pattern modification (changes in the oxygen lance height), were effective for this item.

Higher additions of fluxes; The increase in lime and fluorspar additions were also satisfactory in the achieving the expected results.

- These results are consistent with the available models proposed in the literature describing the phosphorus partition coefficient equilibrium, as shown in this paper.

- The side effect of increasing the efficiency of phosphorus removal was the raise of the refractory wear rate in the converters, due to an increase of slag oxidation, the presence of fluorspar, both associated with higher temperatures at the end of the blow.

\section{REFERENCES}

[1] K. Balajiva, A.G. Quarrel and P.Vajragupta, ISIJ Int. 40 (2000) 964-970.

[2] H.Suito, and R. Inoue, ISIJ Int. 35 (1995) 258268.

[3] G.W. Healy, J. Iron Steel Inst. 208 (1970) 664668.

[4] E.T. Turkdogan, Fundamentals of Steelmaking, $1^{\text {st }}$ Ed. London, The Institute of Materials, 1996, pp. 186-189.

[5] E.T. Turkdogan and J. Pearson, J. Iron Steel Inst. 175 (1953) 393-401. 